\title{
ANALISIS PENGELASAN SMAW TEGANGAN DC TERHADAP KEKUATAN TARIK, KEKERASAN, FOTO MAKRO DAN MIKRO PADA STAINLESS STEEL 304
}

\author{
Harsono*, Sri Mulyo Bondan Respati dan Helmy Purwanto \\ Teknik Mesin, Universitas Wahid Hasyim \\ Jl. Menoreh Tengah x/22, Sampangan, Semarang \\ *Email : harsono27suzuki@gmail.com
}

\begin{abstract}
Abstrak
Penggunaan kuat arus yang berbeda pada pengelasan Stainlees Stell 304 sangat berpengaruh terhadap sifat fisik dan mekanik hasil lasan. Penelitian ini bertujuan mengetahui pengaruh hasil foto makro, struktur mikro, mengujian tidak merusak, pengujian tarik dan juga distribusi kekerasan. Penelitian ini menggunakan bahan plat Stainless Steel 304 dengan ketebalan 8 mm. Selanjutnya spesimen dilakukan pengelasan dengan varisai kuat arus yang berbeda yaitu arus 80 A, 100 A, 120 A. Hasil pengelasan dilakukan pengamatan foto makro, mikro, uji tidak merusak, pengujian tarik dan distribusi kekerasan. Hasil pengujian foto makro menunjukkan pengelasan yang bagus dan halus terletak pada kuat arus 100 A, sedangkan kuat arus $80 \mathrm{~A}$ dan 120 A hasilnya rigi - rigi lasannya kasar, sedangkan hasil pengamatan struktur mikro menunjukkan hasil struktur mikro yang bagus adalah pada arus 100 A karena struktur mikronya halus dan rapat serta di dominasi struktur karbida krom. Hasil pengujian tidak merusak menunjukkan hasil semua lasan tidak ada cacat retak dan cacat porositas. Hasil pengujian tarik yang paling tinggi adalah 434.85 MPa terletak pada arus pengelasan $100 \mathrm{~A}$, sedang distribusi kekerasan yang paling tinggi adalah 90.66 HRB terletak juga pada pengelasan arus $100 \mathrm{~A}$.
\end{abstract}

Kata kunci: stainlees stell, arus, struktur mikro, kekerasan, kekuatan tarik.

\section{PENDAHULUAN}

Pengelasan

merupakan

proses

penyambungan dua buah logam khususnya baja untuk menghasilkan sebuah kontruksi mesin. Sambungan las digunakan untuk menyatukan dua buah baja atau lebih yang bersifat permanen. Penggunaan sambungan las dalam kontruksi mesin misalnya kontruksi casis kendaraan, dudukan mesin industri, sambungan pipa dan lain sebagainya. Penggunaan teknologi las biasanya juga dipakai dalam kontruksi industri makanan, bidang konstruksi, otomotif, perkapalan, pesawat terbang, dan bidang lainnya. Pengelasan cara kerjanya dibagi menjadi tiga kelompok yaitu pengelasan penekanan, pematrian dan pengelasan cair. Pengelasan cair yaitu cara pengelasan dimana benda yang disambung dipanaskan sampai mencair dan menambah logam las dengan sumber energi panas dari mesin las.

Pengelasan yang paling banyak digunakan pada kontruksi mesin adalah pengelasan cair dengan busur (las busur) dan gas (las gas). Jenis las busur listrik dibagi menjadi empat yaitu las busur gas TIG (Tungsten Inert Gas) Las busur elektroda terbungkus, MIG (Metal Inert Gas), Las busur $\mathrm{CO}_{2}$, Las busur tanpa gas dan lan busur rendam. Jenis las busur elektroda terbungkus salah satunya adalah SMAW (Shielding Metal Arc Welding). Pengelasan menggunakan mesin las SMAW dibedakan menjadi tiga yaitu mesin las arus bolak balik (Alternating Current: AC), Mesin las arus searah (Direct Current: DC) dan mesin las arus ganda yang merupakan mesin las yang digunakan untuk pengelasan arus searah maupun arus bolak balik (Soetadrjo, 1997).

Pengelasan pada baja tahan karat adalah salah satu teknologi pengelasan yang membutuhkan proses tertentu karena dalam prosesnya baja tahan karat tidak boleh bereaksi. Material baja tahan karat sangat sering digunakan dalam rancangan kontruksi di industry, terutama industri yang memproduksi makanan. Sifat tahan korosi ini menyebabkan waktu penggunaan dalam jangka yang lama. Penggunaan stainless steel (SS) sebagai material konstruksi di industri sering dilakuan proses penyambungan untuk membentuk komponen sesuai desain yang tepat. Penyambungan tersebut dilakukan melalui proses pengelasan. Sifat mekanik dan performa peralatan dipengaruhi proses pengelasan. Besarnya tegangan sisa akibat pemanasan dari proses pengelasan dapat menurunkan kekuatan suatu material karena adanya tegangan sisa. Hal 
tersebut menyebabkan material lebih mudah mengalami keretakan (Wiryosumarto, 2000) .

Tujuan yang ingin dicapai dalam penelitian ini adalah:

1. Mengetahui dan menganalisa perbedaan makro dan mikro dari hasil pengelasan baja tahan karat pada pengelasan SMAW DC dengan arus pengelasan $80 \mathrm{~A}, 100 \mathrm{~A}$, $120 \mathrm{~A}$.

2. Mengetahui pengaruh perbedaan Cacat permukaan dari hasil pengelasan baja tahan karat pada pengelasan SMAW DC dengan arus pengelasan $80 \mathrm{~A}, 100 \mathrm{~A}, 120$ A.

3. Mengetahui dan menganalisa kekuatan tarik dan disrtibusi kekerasan dari hasil pengelasan baja tahan karat pada pengelasan SMAW DC dengan arus pengelasan $80 \mathrm{~A}, 100 \mathrm{~A} 120 \mathrm{~A}$.

\section{METODOLOGI}

Bahan yang digunakan dalam penelitian ini adalah plat Stainless Stell 304 dengan komposisi kimia: C $0.08 \%$, Mn $2.00 \%$, Si $0.75 \%, \mathrm{P} 0.045 \%$, Cr $20.00 \%$, Ni $12.00 \%$, N 0.10, Fe Balanc ( Royen, 2016 ).

Persiapan Bahan Penelitian antaralain adalah

1. Mempersiapakan bahan yaitu plat Stainless Steel 304 dengan ketebalan $8 \mathrm{~mm}$ lebar $130 \mathrm{~mm}$ dan panjang $250 \mathrm{~mm}$, dengan kampuh V. Mempersiapkan mesin las dan peralatan las berupa las listrik, pemegang elektroda serta jenis elektrodanya sekalian AWS A5.4 E308-16, kabel las, topeng las, sikat baja, palu terak, tang las dan yang lainnya. Pengaturan arus $80 \mathrm{~A}, 100 \mathrm{~A}$ dan 120A. kemudian las kedua ujung benda kerja dengan hati-hati agar tidak terjadi perubahan bentuk dan defleksi dalam pengelasan benda kerja. Bahan seperti Gambar 1.

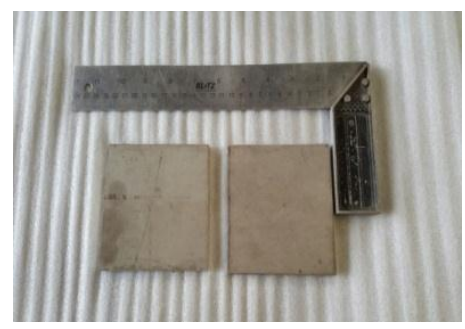

\section{Gambar 1. Bahan Stainlees Stell}

2. Pemotongan bahan dengan menggunakan $\mathrm{CNC}$, dengan ukuran plat $100 \times 100 \times 8 \mathrm{~mm}$ sebanyak 9 buah dan 200 x 100 x 8 mm sebanyak 1 buah Raw material.

3. Membuat kampuh las pada masingmasing pelat yaitu kampuh $\mathrm{V} 60^{\circ}$ seperti terlihat pada Gambar II.

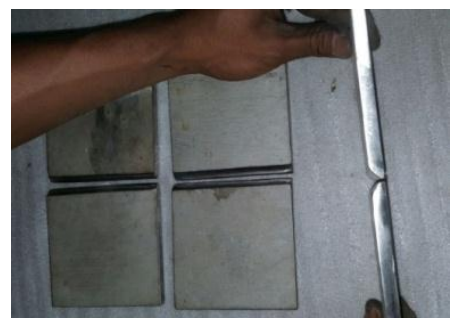

Gambar 2. Stainless Stell dengan Kampuh V

4. Tempatkan benda kerja pada meja kerja las dengan sudut elektroda posisi datar $45^{\circ}-70^{\circ}$, (dari arah pengelasan).

5. Rangkai mesin las SMAW DC

6. Hidupkan mesin las dan atur besar arus sesuai dengan variabel penelitian yaitu $80 \mathrm{~A}, 100 \mathrm{~A}$ dan $120 \mathrm{~A}$.

7. Pasang elektroda pada pemegang las.

8. Pengelasan pada setiap sampel seperti terlihat pada Gambar

9. Pengamatan makro hasil pengelasan seperti terlihat pada Gambar

10. Pengamatan mikro hasil pengelasan.

11. Pengujian kekerasan.

12. Pembuatan spesimen uji tarik seperti terlihat pada Gambar 3.

13. Dimensi spesimen uji tarik seperti pada Gambar 3.

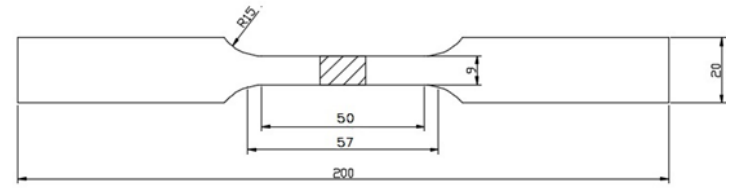

Gambar 3. ASTM E 8M- 09

\section{HASIL DAN PEMBAHASAN}

Material stainless steel AISI 304 memiliki kandungan Carbon (C), dimana carbon mempunyai sifat dapat meningkatkan kekerasan dan kekuatan tetapi dapat menurunkan kemampuan tempa dan keliatan. kandungan Crom ( $\mathrm{Cr}$ ) sebanyak $11-20 \%$ Unsur Chromium dapat memberikan pengaruh yang besar terutama dalam proses kimia pada saat proses pemanasan yaitu terjadinya peristiwa sensitasi pada baja sehingga mengakibatkan peningkatan kwalitas bahan tersebut, Nikel ( $\mathrm{Ni}$ ) sebanyak $8-12 \%$, dan Mangan ( $\mathrm{Mn}$ ) $3-4 \%$ karena mangan 
merupakan unsur deoksidasi dan khususnya sebagai pengikat unsur belerang (S), pemurni sekaligus meningkatkan fluiditas, kekuatan dan kekerasan baja. Baja dengan kandungan Mn tinggi tidak mudah patah pada temperatur tinggi. Bila kadarnya semakin besar dalam baja maka kemungkinan meningkatkan

terbentuk ikatan kompleks dengan karbon. Stainlees steell 304 dipilih sebagai material kerja dikarenakan sifat tahan panas pada temperatur tinggi dan sifat ketahanan korosinya yang sangat baik.

\section{Hasil Foto Makro}

Hasil pengamatan foto makro pada pengelasan bahan plat Stainless Steel 304 Hasilnya terlihat pada Gambar 4.

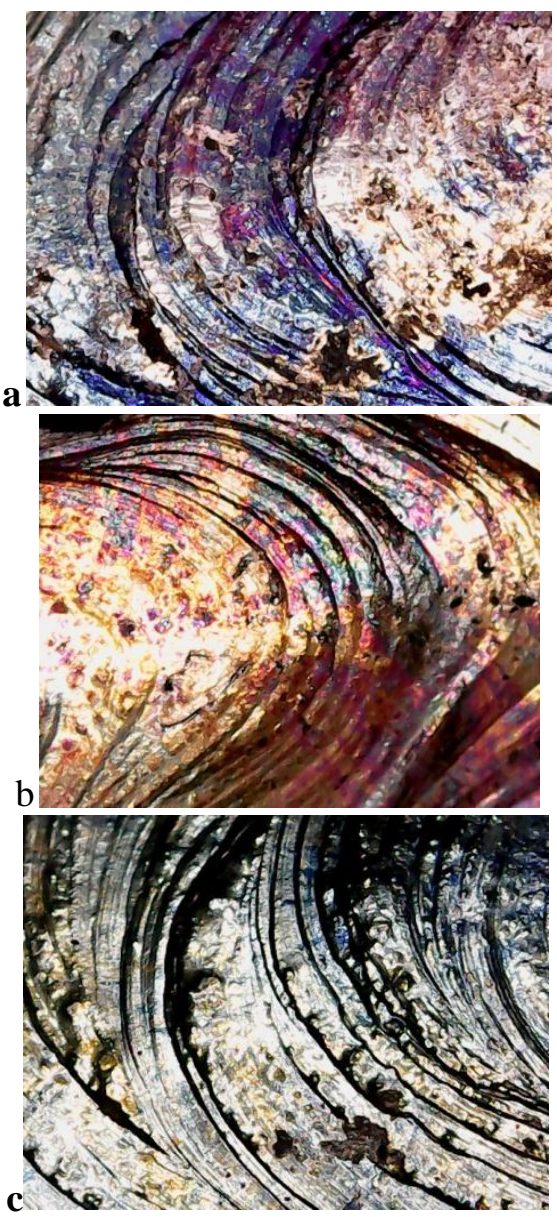

\section{Gambar 4. Hasil foto Makro, a.Pengelasan Arus 80 A, b. 100 A, c. 120 A}

Hasilnya yang paling bagus adalah pada pengelasan dengan menggunakan kuat arus 100 A, sedangkan pada pengelasan yang menggunakan Arus 80 A agak kasar dikarenakan arus yang digunakan kecil jadi kurang sempurna untuk melumerkan material dan Arus 120 A hasilnya kurang bagus terlihat rigi-riginya kasar, ini juga disebabkan karena terjadinya lubang dari HAZ terlihat kasar. Semua perbedaan tersebut memang dipengaruhi oleh besar kecilnya kuat Arus yang dipakai dalam pengelasan, serta juga kecepatan dalam pengelasan.

\section{Hasil foto Mikro}

Pengamatan posisi daerah hasil mikronya antara lain daerah raw material, HAZ, las. Seperti terlihat pada Gambar 5.

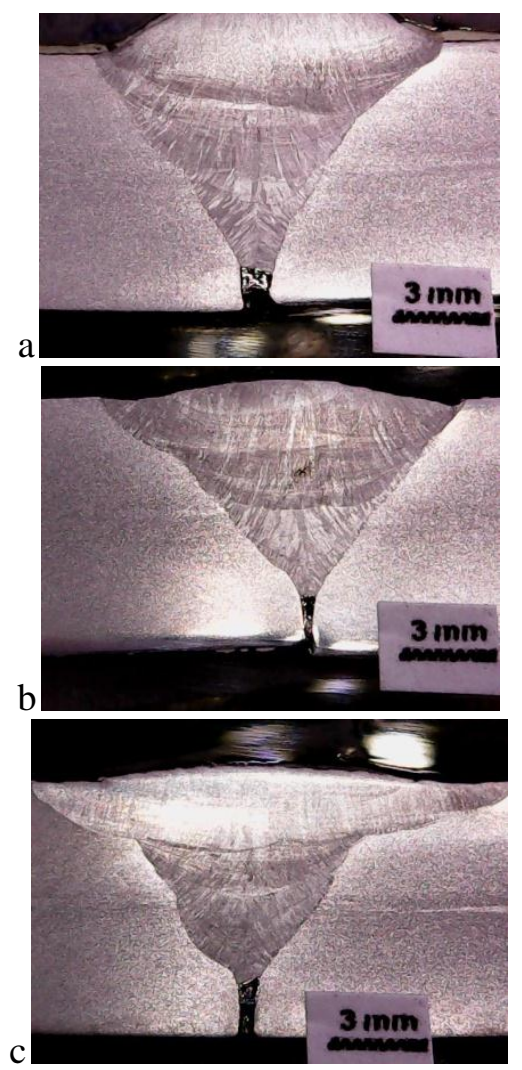

\section{Gambar 5. Foto makro setelah dietza a.Arus 80 A b, Arus 100 A, c.Arus 120}

Hasil makro atau juga bisa disebut secara visual bahan plat Stainless Stell 304 yang telah dilas, kemudian juga dipotong serta dihaluskan. Bahan yang dihaluskan tadi kemudian dietsa, maka terlihatlah perbedaan antara pengelasan dengan kuat Arus 80 A, kuat Arus 100 A dan kuat Arus 120 A. Pada gambar V ( a) dilas dengan arus 80 A hasil sudut kambuhnya tidak jauh berbeda dengan kampuh awal, dan pada gambar V (b) dilas dengan arus 100 A hasil sudut kampuhnya lebih lebar sedikit dengan kampuh awal, dan pada gambar $\mathrm{V}$ (c) dilas dengan arus 120 A hasil sudut kampulnya lebih 
lebar ini dikarena adanya overheat pada pengelasan tersebut. Semakin besar Arus semakin besar pula panas yang mengakibatkan overheat.

\section{a. Struktur mikro Raw Material}

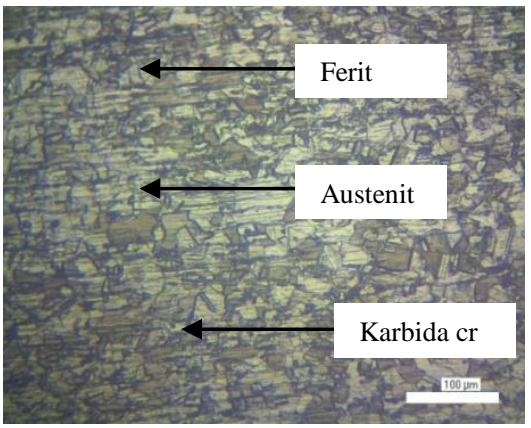

\section{Gambar 6. Raw material}

Terlihat sangat jelas bahwa hasil pengujian pada struktur mikro pada hasil uji metallografi raw material menunjukkan ada tiga fasa yang terlihat yaitu: fasa ferit ( kelihatan warna hitam), fasa austenite ( terlihat warna terang), dimana fasa austenite disini lebih mendominasi dan fasa karbida $\mathrm{Cr}$ (terlihat warna titik hitam kecil), fasa ini sangat sedikit sekali karena belum ada perlakuan sama sekali.

Tabel 1 perbedaan mikro HAZ dan LAs

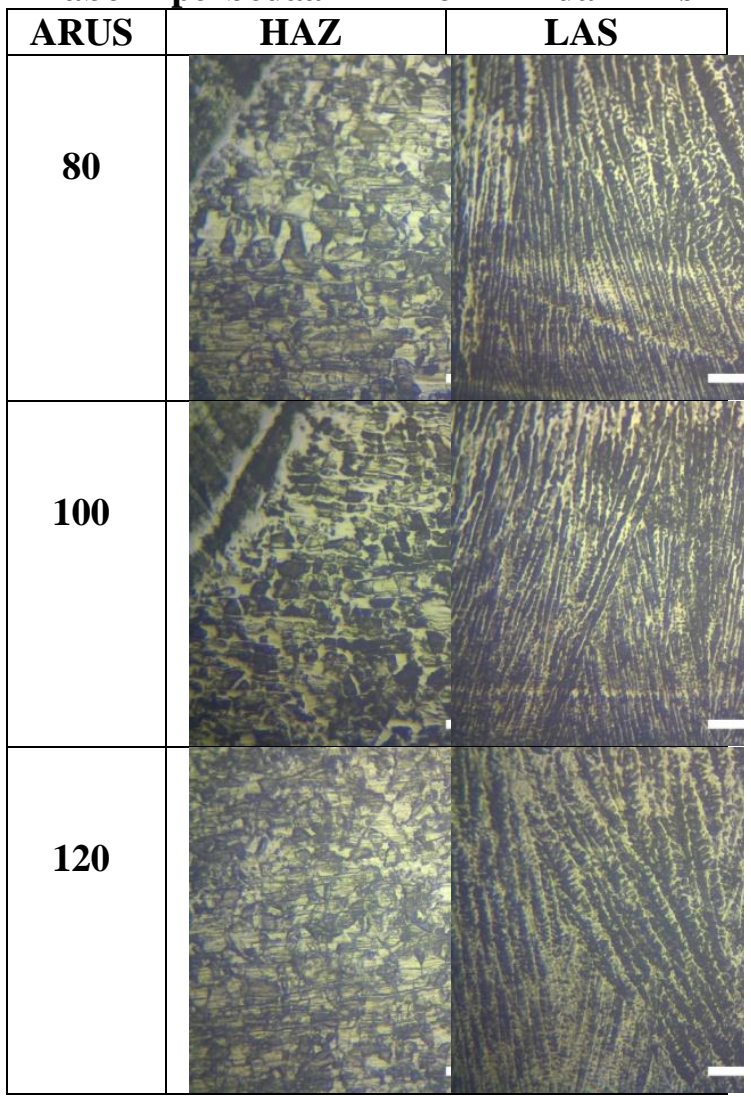

Pada Tabel 1 menunjukan perbedaan hasil struktur mikro pada daerah HAZ dan daerah las. Perbedaan struktur mikro pada daerah HAZ menunjukkan bahwa pada pengelasan kuat arus $80 \mathrm{~A}$ menghasilkan struktur mikro ferit, austenite dan karbida crom, tapi lebih didominasi austenite dan karbida cromnya sedikit. Pada pengelasan dengan kuat arus $100 \mathrm{~A}$ hasil struktur mikronya ferit, austenite dan karbida crom, akan tetapi feritnya dihasilkan lebih gelap dan karbida cromnya lebih banyak dibandingan dengan 80 A tadi. Pada pengelasan dengan kuat arus 120 A hasil struktur mikronya ferit, austenite dan karbida crom, akan tetapi hasilnya hampir sama dengan pengelasan pada arus $80 \mathrm{~A}$.

Perbedaan struktur mikro pada daerah las menunjukkan bahwa pada pengelasan kuat arus 80 A menghasilkan struktur mikro ferit, austenite dan karbida crom yang kasar. Pada pengelasan dengan kuat arus 100 A hasil struktur mikronya ferit, austenite dan karbida crom lebih halus dibandingan mikro pada pengelasan arus $80 \mathrm{~A}$. Pada pengelasan dengan kuat arus 120 A hasil struktur mikronya ferit, austenite dan karbida crom kasar, hasilnya hampir sama dengan pengelasan pada arus 80 A.

\section{Hasil Uji Tarik}

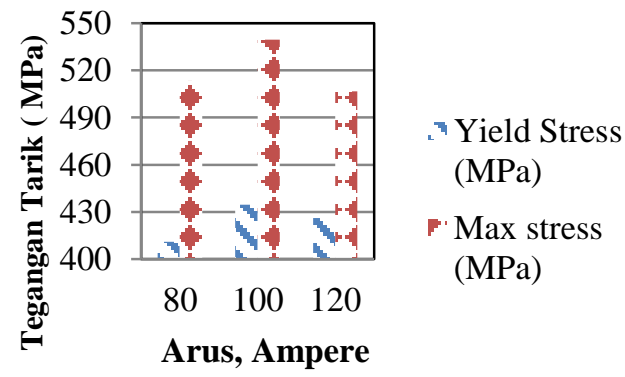

\section{Gambar 7. Grafik pengujian tarik}

Pada Gambar 7 menunjukkan bahwa hasil tegangan tarik yang paling tinggi 434.85 $\mathrm{MPa}$ terletak pada pengelasan dengan menggunakan kuat arus 100 A karena struktur mikro karbida kromnya lebih banyak dibandingkan kuat arus yang lain. sedangkan tegangan tarik dengan nilai rendah $411.16 \mathrm{MPa}$ terletak pada pengelasan dengan kuat arus $80 \mathrm{~A}$. Tegangan tarik maksimal nilai tertinggi 539.58 MPa juga terletak pada pengelasan dengan kuat arus 100 A. Adapun hal hal yang mempengaruhi hasil pengujian Menurut 
penelitian yang dilakukan Yakub, bahwa semakin besar arus pengelasan untuk SS 304 akan menurunkan kekuatan tarik maksimum dan saat pengujian tarik material putus di daerah HAZ.

\section{Hasil Pengujian Kekerasan}

Pengujian kekerasan Rockwell (HRB) yang telah dilakukan menghasilkan data dari logam induk, daerah las dan daerah HAZ dengan variasi Arus yang telah dilakukan seperti Gambar 8

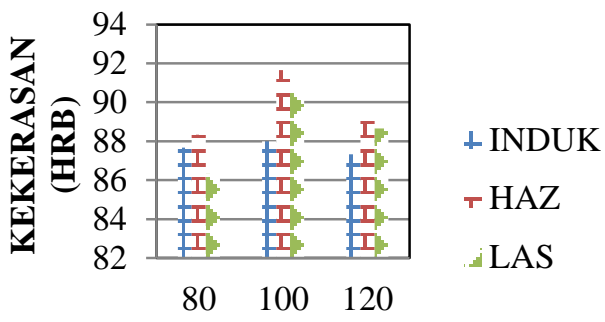

Arus, Ampere

\section{Gambar 8.Hasil uji kekerasan}

Pada Gambar 8 Grafik kekerasan Rockwell menunjukkan bahwa kekerasan pada daerah HAZ yang paling tinggi adalah 91.66 HRB terjadi pada pengelasan dengan menggunakan kuat Arus $100 \mathrm{~A}$, dan nilai kekerasan yang paling rendah adalah 88.33 HRB yang terjadi pada pengelasan dengan menggunakan kuat Arus 80 A. Nilai kekerasan pada daerah las tertinggi adalah 90.66 HRB terjadi pada pengelasan dengan kuat arus 100 A dikarena hasil struktur mikro karbida crom lebih banyak, dimana sifat karbida krom itu keras. Nilai terrendah adalah 86.33 HRB terjadi pada pengelasan dengan menggunakan kuat Arus 80 A. Adapun hal hal yang mempengaruhi hasil pengujian kekerasan menurut penelitian yang dilakukkan setiawan bahwa secara umum untuk daerah las lebih lunak dibandingkan daerah HAZ maupun logam induk, Karena suplay panas yang paling tinggi maka butir butir logam akan membesar dan menurunkan kekerasan.

\section{Hasil Pengujian Tidak Merusak}

Hasil pengujian Non Destructive Test menggunakan Metode Liquid Penetrant Test seperti terlihat pada Gambar 9.

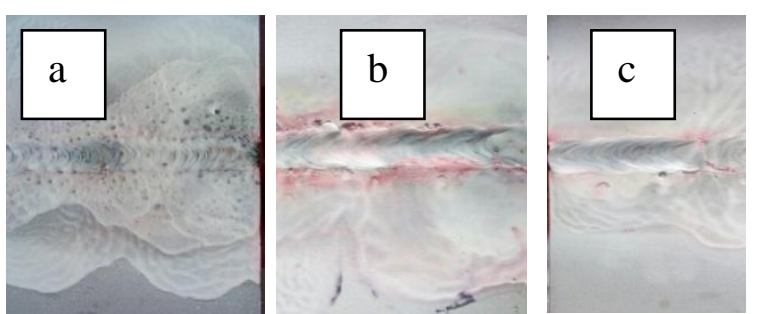

\section{Gambar 9. Hasil uji tidak merusak}

Pada Gambar 9 menunjukkan bahwasaannya hasil pengelasan dengan kuat Arus 80 A, 100 A dan 120 A tidak menunjukkan cacat, baik cacat porositas ataupun cacat retak pada permukaaan setelah diuji dengan penetrant. Pengujian dengan penetrant ini akan menunjukkan cacatcacat halus yang disebabkan karena pengelasan yang baik. Hasil pengelasan yang cacat atau porositas akan terlihat ada bintik-bintik merah, namun hasilnya setelah dilakukan pengujian tidak ada cacat sedikitpun. Hasil tersebut terjadi karena temperature pengelasan cukup untuk melelehkan atau melumerkan dua material yang akan disambung.Hasil pengelasannya cukup halus dan cukup bagus.

\section{KESIMPULAN}

1. Hasil pengujian foto makro menunjukkan pengelasan yang bagus dan halus terletak pada kuat arus $100 \mathrm{~A}$, sedangkan kuat arus 80 A dan 120 A hasilnya rigi - rigi lasannya kasar, sedangkan hasil pengamatan struktur mikro menunjukkan hasil struktur mikro yang bagus adalah pada arus 100 A karena struktur mikronya halus dan rapat serta di dominasi struktur karbida krom.

2. Hasil pengujian tidak merusak menunjukkan hasil semua lasan tidak ada cacat retak dan cacat porositas.

3. Hasil pengujian tarik yang paling tinggi adalah 434.85 MPa terletak pada arus pengelasan $100 \mathrm{~A}$, sedang distribusi kekerasan yang paling tinggi adalah 90.66 HRB terletak juga pada pengelasan arus $100 \mathrm{~A}$.

\section{DAFTAR PUSTAKA}

Dieter, George E. 1987. Metalurgi Mekanik. Jakarta: Erlangga.

Dewa , C, 2004, Analisa proses quenching pada stainless steel seri 304 produk di pasaran. Teknik Mesin Universitas Muhammadiyah Surakarta. 
Mega, 2015, "Pengaruh Suhu Preheating pada Hasil Pengelasan GTAW terhadap Sifat Fisis dan Mekanis Stainless Steel 304.

Naryono dan Rahman F., 2013. Pengaruh variasi kecepatan pengelasan pada penyambungan pelat baja SA 36 menggunakan elektroda E6013 dan E7016 terhadap kekerasan, struktur mikro dan kekuatan tariknya.

Putra, 2011, Analisa hasil pengelasan SMAW pada baja tahan karat Feritik dengan variasi arus dan elektroda. Institut Teknologi Sepuluh Nopember Surabaya, 2011.

Royen, 2016, Memahami Komposisi dan Spesifikasi Stainless Steel Tipe 304 dan 304L,http://abi-blog.com/memahami-

komposisi-dan-spesifikasi-stainless-steeltipe-304-dan-3041.

Soetardjo, 1997. Petunjuk praktek las asitelin dan las listrik.

Sonawan, H,2003, Las Listrik SMAW dan Pemeriksaan Hasil Pengelasan.

Supardi, E., 1996, Pengujian Logam Angkasa, Bandung.

Setyo dan Rendy P., 2013.Pengaruh Kecepatan Pengelasan dan Jenis Elektroda Terhadap Kekuatan Tarik Hasil Pengelasan SMAW baja ST 60, Jurnal Teknik Mesin Univ. Brawijaya Malang.

Santoso J., 2006. Pengaruh arus pengelasan terhadap kekuatan tarik dan ketangguhan las SMAW dengan elektroda E7018.

Setyowati, 2016, Variasi arus dan sudut pengelasan pada material Austenitic stainless steel 304 terhadap kekuatan Tarik dan struktur makro. Teknik Mesin - Institut Teknologi Adhi Tama Surabaya.

Wiryosumarto, H., 2000, Teknologi Pengelasan Logam, Erlangga, Jakarta.

Wiryosumarto, H. dan T. Okumura. 2000. Teknologi Pengelasan Logam. Jakarta: PT. Pradya Paramita.

Widodo dan Suheini, 2016, Pengaruh kuat arus listrik dan jenis kampuh las Terhadap kekerasan dan strukturmakro pada Pengelasan Stainless steel AISI 304. Intitut Teknologi Adhi Tama Surabaya.

Yunus dan Nofri, 2013, Variasi arus listrik terhadap Sifat mekanik mikro sambungan las baja tahan Karat aisi 304, Volume 1 Nomor 1 Juli-Desember 2013, E-Journal WIDYA Eksakta.

Yakub, Y, 2013, Variasi Arus Listrik terhadap Sifat Mekanik Mikro Sambungan Las Baja
Tahan Karat AISI 304. E-journal Widya Eksakta. 1(1).

Setiawan, A , 2016, Penelitian stainless steel 304 terhadap pengaruh pengelasan ( gas tungsten arc welding GTAW untuk variasi arus 50A,100A dan 160A dengan uji kompossi,uji struktur mikro, uji kekerasan dan uji impact.Universitas Muhammadiyah Surakarta. 